\title{
'Candidatus Phytoplasma castaneae', a novel phytoplasma taxon associated with chestnut witches' broom disease
}

\footnotetext{
${ }^{1}$ Laboratory of Plant Pathology, The University of Tokyo, 1-1-1 Yayoi, Bunkyo-ku, Tokyo 1138657, Japan

2 Laboratory of Bioresource Technology, The University of Tokyo, 202 Frontier Bioscience Building, Kashiwa, Chiba 277-8562, Japan

${ }^{3}$ Laboratory of Plant Pathology, Kyungpook National University, Taegu 702-701, Korea
}

\author{
Hee-Young Jung, ${ }^{1}$ Toshimi Sawayanagi, ${ }^{2}$ Shigeyuki Kakizawa, ${ }^{2}$ \\ Hisashi Nishigawa, ${ }^{2}$ Shin-ichi Miyata, ${ }^{2}$ Kenro Oshima, ${ }^{2}$ Masashi Ugaki, ${ }^{2}$ \\ Joon-Tak Lee, ${ }^{3}$ Tadaaki Hibi ${ }^{1}$ and Shigetou Namba ${ }^{2}$
}

Author for correspondence: Shigetou Namba. Tel: +8147136 3700. Fax: +81471363701. e-mail: snamba@ims.u-tokyo.ac.jp

\begin{abstract}
In Korea, Japanese chestnut trees (Castanea crenata Sieb. and Zucc.) showing symptoms indicative of witches' broom disease, including abnormally small leaves and yellowing of young leaves, were examined. Since the symptoms were suggestive of a phytoplasma infection, tissues were assayed for phytoplasmas by PCR analysis using a pair of universal primers that amplify a 1.4-kbp phytoplasma $16 \mathrm{~S}$ rDNA fragment. The phytoplasma-specific fragment was amplified from diseased plants, but not from healthy plants, indicating that a phytoplasma was the causal agent of the chestnut witches' broom (CnWB) disease. The phylogenetic relationship of the CnWB phytoplasma to other phytoplasmas was examined by sequence analysis of the 16S rDNA. A phylogenetic analysis of 165 rDNA sequences of the phytoplasmas placed the CnWB phytoplasma within a distinct subgroup in the phytoplasma clade of the class Mollicutes. The phylogenetic tree indicated that the CnWB phytoplasma is related most closely to coconut phytoplasmas and suggested that they share a common ancestor. The unique properties of the CnWB phytoplasma sequences clearly establish that it represents a novel taxon, 'Candidatus Phytoplasma castaneae'.
\end{abstract}

Keywords: 'Candidatus Phytoplasma castaneae'

\section{INTRODUCTION}

Phytoplasmas are prokaryotes that lack a cell wall and are the causal agents of numerous plant diseases (McCoy et al., 1989; Kirkpatrick, 1992). Phytoplasmas inhabit sieve elements in the phloem of plants and are transmitted between plants by phloem-feeding insects. Phytoplasmas are small enough to pass through bacteriological filters and, like mycoplasmas, are resistant to antibiotics that interfere with cell-wall formation. Chestnut trees (Castanea spp.) are grown widely in the temperate zone of the northern hemisphere as commercially important vegetable crops. The chestnut phytoplasma disease was first described tentatively as a graft-transmissible viral disease in

Abbreviations: CLL, chestnut little leaf; CnWB, chestnut witches' broom. The EMBL/DDBJ/GenBank accession number for the $16 \mathrm{~S}$ rDNA sequence of 'Candidatus Phytoplasma castaneae' reported in this paper is AB054986.
Japanese chestnut, Castanea crenata Sieb. and Zucc., in Japan, and was named chestnut yellows disease (Shimada \& Kouda, 1954). However, it was later shown by transmission electron microscopy that a phytoplasma was associated with the disease (Okuda et al., 1974). In Korea in 1993, chestnut trees showing the typical symptoms of small, yellow leaves were examined. Based on electron and fluorescence microscope analysis, a phytoplasma was implicated as the aetiological agent of the disease (Han et al., 1997). It was named chestnut little leaf (CLL) disease, reflecting the most obvious symptom. In Italy, European chestnut trees (Castanea sativa Mill) showing small, yellowing leaves have also been found in chestnut orchards, but it is still not known whether the causal disease was associated with phytoplasmas (Mittempergher \& Sfalanga, 1998).

In Korea, Japanese chestnut trees showing the typical witches' broom symptoms, suggestive of phytoplasma 
infection, have been observed. The disease, tentatively denoted as chestnut witches' broom (CnWB), also resulted in small, yellowing leaves, but differed from Korean CLL and the chestnut yellows of Japan in symptom severity; it has led to severe crop losses, particularly in Kyongnam and Chonbuk provinces.

RFLP analysis of PCR-amplified 16S rDNA provides a simple, rapid and reliable method to differentiate and classify unidentified phytoplasmas (Lee et al., 1993; Prince et al., 1993). The development of universal PCR primer pairs designed to amplify all known phytoplasma 16S rDNA has facilitated this approach significantly (Ahrens \& Seemüller, 1992; Deng \& Hiruki, 1991; Gundersen \& Lee, 1996; Namba et al., 1993a). Moreover, nucleotide sequence analyses of the amplified 16S rDNA fragments have made phylogenetic analysis of phytoplasma isolates possible, and the information obtained has been used as the basis for delineating phytoplasmas into several groups (Kuske \& Kirkpatrick, 1992; Schneider et al., 1995; Seemüller et al., 1998; White et al., 1998).

In this study, we have demonstrated that the pathogen causing CnWB is indeed a phytoplasma (CnWB phytoplasma). We then determined the phylogenetic placement of the CnWB phytoplasma by amplifying and sequencing its $16 \mathrm{~S}$ rDNA. Our results indicate clearly that this phytoplasma is unique among all previously described phytoplasmas. We also identified nucleotide sequences unique to the CnWB phytoplasma 16S rDNA, which will allow specific detection of this phytoplasma.

\section{METHODS}

Source of phytoplasma strains. Samples from Japanese chestnut trees (Castanea crenata Sieb. and Zucc.) displaying disease symptoms of $\mathrm{CnWB}$ and from trees without symptoms were collected from several independent diseased areas in Kyongnam and Chonbuk provinces in Korea. Healthy tissues were collected from greenhouse-grown chestnut seedlings.

Primer pairs and PCR conditions. Total nucleic acids were extracted from tissues as described previously (Namba et al., 1993a) for use as PCR templates. The extracted nucleic acids were quantified by agarose gel electrophoresis. A pair of previously designed universal primers (SN910610 and SN910502; Namba et al., 1993a) was used to amplify 16S rDNA in each sample tested. PCR conditions were described previously (Sawayanagi et al., 1999). PCR products were electrophoresed in $0.7 \%$ agarose gels in TAE buffer and visualized with a UV transilluminator following ethidium bromide staining.

Nucleotide sequencing and PCR specific for CnWB phytoplasma. Primers used to sequence the 16S rDNA were reported previously (Namba et al., 1993a, b). The PCRamplified 16S rDNA products of at least ten independent CnWB-infected plant samples were sequenced using Dye Terminator cycle sequencing kits (Applied Biosystems). A pair of oligonucleotides was designed for specific amplification of CnWB phytoplasma DNA according to the $16 \mathrm{~S}$ rDNA sequence. PCR conditions were as described by
Sawayanagi et al. (1999) except that the annealing temperature was $54^{\circ} \mathrm{C}$ and 30 cycles were run.

Cladogram construction. Nearly complete 16S rDNA sequences from almost all phytoplasmas reported and from Acholeplasma palmae (Table 1) were aligned with that from the CnWB phytoplasma using the program CLUSTAL W (Thompson et al., 1994) and base positions were numbered using a previously described system (Namba et al., 1993b). Sequences of other organisms used in this study were obtained from the DDBJ. Nucleotide substitution rates ( $K_{\text {nue }}$ values) were calculated (Kimura, 1980) and a phylogenetic tree was constructed using the neighbour-joining method (Saitou \& Nei, 1987), with A. palmae as the outgroup. The topology of trees was evaluated by bootstrap analysis of the sequence data with CLUSTAL w, based on 100 random samplings.

Nucleotide sequence accession numbers. GenBank accession numbers of the $16 \mathrm{~S}$ rDNA sequences of the CnWB phytoplasma and other phytoplasmas used in this study and of $A$. palmae are listed in Table 1.

\section{RESULTS AND DISCUSSION}

\section{Detection of phytoplasma in diseased chestnut trees}

PCR using universal primers SN910610 and SN910502 was used to amplify the phytoplasma $16 \mathrm{~S}$ rDNA and detected one fragment, approximately $1.4 \mathrm{kbp}$ in size, representing the $16 \mathrm{~S}$ rDNA of the phytoplasmas in all diseased chestnut trees examined (data not shown). Under the same conditions, no amplification products were obtained from asymptomatic plants collected from the same area or from healthy plants grown in a greenhouse.

\section{Nucleotide sequencing of amplified 16S rDNA from the CnWB phytoplasma}

Many phytoplasmas have been classified by analysing 16S rDNA sequences and RFLP profiles (Tymon et al., 1997; Montano et al., 2000). Sequence analysis of $16 \mathrm{~S}$ rDNA has also played an important role in the description of novel phytoplasma species (Zreik et al., 1995; Davis et al., 1997; White et al., 1998; Griffiths et al., 1999; Sawayanagi et al., 1999; Montano et al., 2001). This study used similar approaches to determine the phylogenetic relationships between the CnWB phytoplasma and other phytoplasmas.

All of the 16S rDNA sequences of the CnWB phytoplasma isolated from several independent areas were identical (data not shown).

\section{Sequence similarity and phylogenetic relationships}

Sequence comparisons revealed that similarity between the CnWB phytoplasma and other phytoplasmas ranged from 86.8 to $94.9 \%$ and that between the CnWB phytoplasma and other mollicutes ranged from $70 \cdot 1$ to $86 \cdot 4 \%$. Stackebrandt \& Goebel (1994) proposed that any two bacteria having 16S rRNA similarity of $97 \%$ or higher needed additional data before they could be classified into different species. 
Table 1. Strains of phytoplasma and Acholeplasma used in this study, associated diseases and 16S rDNA sequence accession numbers

\begin{tabular}{|c|c|c|c|c|c|}
\hline Strain & Associated plant disease & $\begin{array}{c}\text { 16S rDNA } \\
\text { accession no. }\end{array}$ & Strain & Associated plant disease & $\begin{array}{c}\text { 16S rDNA } \\
\text { accession no. }\end{array}$ \\
\hline AAY & American aster yellows & X68373 & LDT & Tanzanian coconut lethal disease & $\mathrm{X} 80117$ \\
\hline ACLR & Apricot chlorotic leaf roll & X68338 & LDY & Yucatan coconut lethal decline & U18753 \\
\hline AGY & Australian grapevine yellows & X95706 & LfWB & Loofah witches' broom & L33764 \\
\hline AlfS & Alfalfa stunt & AF177384 & LWB3 & Lilac witches' broom & AF105317 \\
\hline $\mathrm{AlY}$ & Alder yellows & Y16387 & LY & Coconut lethal yellowing & U18747 \\
\hline APS & Apple proliferation & X76426 & MIAY & Michigan aster yellows & M30970 \\
\hline AshY & Ash yellows & X68339 & OAY & Oenothera aster yellows & M30790 \\
\hline AshY1 & Ash yellows & AF092209 & OY & Onion yellows & D12569 \\
\hline AshY2 & Ash yellows & AF189215 & PaWB & Paulownia witches' broom & AF279271 \\
\hline AshY3 & Ash yellows & AF105315 & PD & Pear decline & X76425 \\
\hline AshY4 & Ash yellows & L33759 & PD-I & Pear decline & Y16392 \\
\hline AshY5 & Ash yellows & AF105316 & PEP & Picris echioides phyllody & Y16393 \\
\hline AT & Apple proliferation & X68375 & PEY & Picris echioides yellows & Y16389 \\
\hline AUSGY & Australian grapevine yellows & L76865 & PnWB & Peanut witches' broom & L33765 \\
\hline AY-H & Ash yellows & AF245439 & PpDB & Papaya dieback & Y10095 \\
\hline AY1 & Maryland aster yellows & L33767 & PPER & European stone fruit yellows of peach & $\mathrm{X} 68374$ \\
\hline BAWB & Black alder witches' broom & X76431 & PPLL & Pigeon pea little leaf & AJ 289191 \\
\hline $\mathrm{BB}$ & Tomato big bud & L33760 & $\mathrm{PpM}$ & Papaya mosaic & Y10096 \\
\hline BGWL & Bermudagrass white leaf & Y16388 & PPT & Potato purple top & AF217247 \\
\hline BLL & Brinjal little leaf & X83431 & PPWB & Pigeon pea witches' broom & L33735 \\
\hline BLWB & Black locust witches' broom & AF244363 & PPWB-Ch & Chinese pigeon pea witches' broom & AF028813 \\
\hline BoLL & $\mathrm{NK}$ & Y15863 & PpYC & Papaya yellow crinkle & Y10097 \\
\hline BVK & Blutenverkleinerung & X76429 & PYL1 & Phormium yellow leaf & $\mathrm{U} 43569$ \\
\hline $\mathrm{CaC}$ & Cactus phytoplasma & AF200718 & PYL2 & Phormium yellow leaf & $\mathrm{U} 43570$ \\
\hline ChWB-C & Chayote witches' broom & AF147706 & PYLR & Peach yellow leaf roll & Y16394 \\
\hline ChWB-M & Chayote witches' broom & AF 147707 & $\mathrm{RpPh}$ & Rape phyllody & U89378 \\
\hline CIRP & Cirsium arvense phyllody & X83438 & RuS & Rubus stunt & Y16395 \\
\hline CnWB & Chestnut witches' broom & AB054986 & RYD & Rice yellow dwarf & D12581 \\
\hline $\mathrm{CP}$ & Clover proliferation & L33761 & SAY & Western severe aster yellows & M86340 \\
\hline $\mathrm{CPh}$ & Clover phyllody & L33762 & SCWL & Sugarcane white leaf & X76432 \\
\hline $\mathrm{CPhI}$ & Italian clover phyllody & $\mathrm{X} 77482$ & ScYPI-Ba & Sugarcane yellows & AF056094 \\
\hline CPPWB & Caribbean pigeon pea witches' broom & U18763 & SLL & Stylosanthes little leaf & AJ289192 \\
\hline $\mathrm{CX}$ & Canadian peach X-disease & L33733 & SLY & Strawberry lethal yellows & AJ 243045 \\
\hline CYE & Clover yellow edge & L33766 & SPAR & Spartium witches' broom & X92869 \\
\hline CYE-C & Clover yellow edge & AF175304 & SPLL & Sweet potato little leaf & X90591 \\
\hline CYE-L & Clover yellow edge & AF 173558 & SPWB & Sweet potato witches' broom & L33770 \\
\hline CYE-Or & Clover yellow edge & AF 189288 & StGP & Strawberry green petal & AJ243044 \\
\hline Elm-AH & Elm phytoplasma & AF268895 & StLL & Stylosanthes little leaf & Y17055 \\
\hline ESFY & European stone fruit yellows of apricot & Y11933 & STOL & Stolbur of Capsicum annuum & $\mathrm{X} 76427$ \\
\hline EY & Elm yellows & L33763 & STRAWB1 & Strawberry witches' broom & U96614 \\
\hline EY1 & Elm yellows & AF 122910 & STRAWB2 & Strawberry witches' broom & U96616 \\
\hline EY2 & Elm yellows & AF189214 & SunHP & Sun hemp witches' broom & X76433 \\
\hline FBP & Faba bean phyllody & X83432 & SVN & Soybean veinal necrosis & AF177383 \\
\hline FD & Flavescence dorée of grapevine & $\mathrm{X} 76560$ & TBB & Australian tomato big bud & Y08173 \\
\hline FM & Fragaria multicipita phytoplasma & AF036354 & TBB-A & Australian tomato big bud & AJ289194 \\
\hline GaLL & Galactia little leaf & Y15865 & TWB & Tsuwabuki witches' broom & D12580 \\
\hline $\mathrm{GPh}$ & Gerbera phyllody & AB026155 & ULW & Ulmus witches' broom & X68376 \\
\hline HD1 & Hemp dogbane & AF122912 & VAC & Vaccinium witches' broom & $\mathrm{X} 76430$ \\
\hline HibWB & Hibiscus witches' broom & AF147708 & VGR & Virginia grapevine yellows & AF060875 \\
\hline IAWB & Italian alfalfa witches' broom & Y16390 & ViLL & Vigna little leaf & Y15866 \\
\hline IBS & Italian bindweed stolbur & Y16391 & VK & Grapevine yellows & X76428 \\
\hline JHP & Japanese Hydrangea phyllody & $\mathrm{AB} 010425$ & VLL & Vigna little leaf & AJ289195 \\
\hline KAP & Knautia arvensis phyllody & Y18052 & WBDL & Witches' broom disease of lime & U15442 \\
\hline KV & Clover phyllody & $\mathrm{X} 83870$ & WVEY & Elm yellows & AF122911 \\
\hline LDG & Ghanaian Cape St Paul's wilt disease & Y13912 & WX & Western X-disease & L04682 \\
\hline LDN & Nigerian Awka disease & Y14175 & A. palmae & - & L33734 \\
\hline
\end{tabular}

NK, Not known.

Thus, the CnWB phytoplasma can safely be considered to constitute a novel taxon or species. For phylogenetic analysis, CnWB phytoplasma 16S rDNA sequences were aligned with those of most reported phytoplasmas (Table 1). Phylogenetic analysis of $16 \mathrm{~S}$ rDNA sequences from 110 diverse phytoplasmas, plus CnWB phytoplasma and $A$. palmae, produced one neighbourjoining tree (Fig. 1). Bootstrap analysis revealed that the phylogenetic tree was reliable and it was also in good agreement with a tree constructed previously with 57 phytoplasma accessions (Seemüller et al., 1998). As a result of using a larger number of accessions, the current tree has several additional branches. The tree indicated that the CnWB phytoplasma constitutes a distinct branch, with a long phylogenetic distance from any other phytoplasma. The tree also indicated that the CnWB phytoplasma branch is included in a larger group that includes three other branches: a branch composed of LDG plus LDN, the branch containing LDT and a branch 

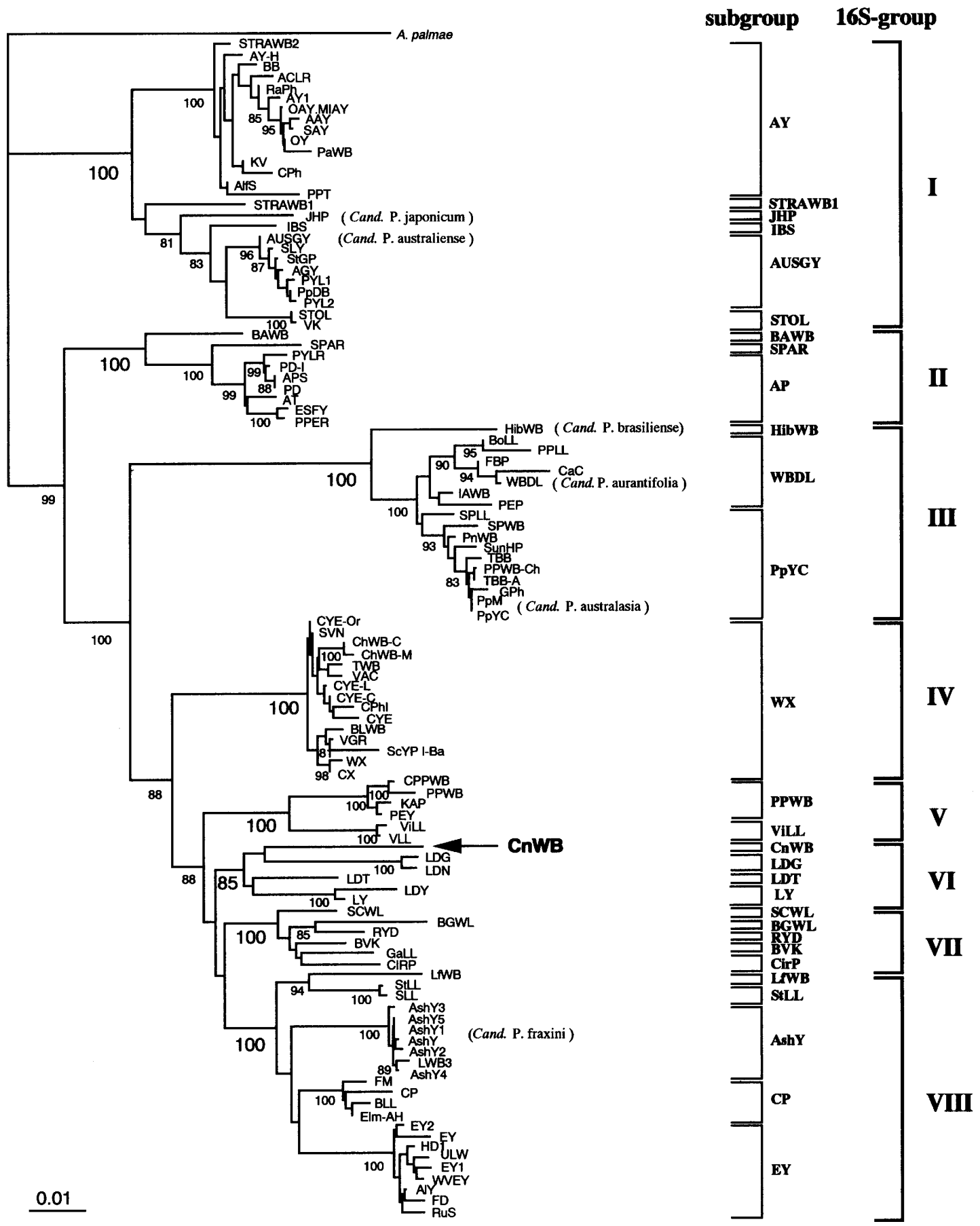

Fig. 1. Phylogenetic distance tree constructed by the neighbour-joining method, comparing the nearly complete $16 \mathrm{~S}$ rDNA sequence of the CnWB phytoplasma with those of other phytoplasmas from GenBank. Acholeplasma palmae was used as the outgroup. Numbers on the branches are confidence values obtained for 100 replicates (only values above $80 \%$ are shown). The bar represents a phylogenetic distance of $1 \%$. Phytoplasma abbreviations are described in Table 1.

composed of LDY plus LY. Except for the CnWB phytoplasma, all of the phytoplasmas included in this larger group infect the coconut. Judging from the branch lengths between CnWB and these other phytoplasmas, the CnWB phytoplasma may have diverged from $\mathrm{LDG} / \mathrm{LDN}$ and related phytoplasmas early in the evolution of this phytoplasma group.
RFLP and heteroduplex mobility analyses of amplified phytoplasma $16 \mathrm{~S}$ rDNA revealed that the pathogen that causes CLL disease, which has symptoms similar to $\mathrm{CnWB}$, was a phytoplasma closely related to aster yellows (AY) phytoplasma (Hiruki et al., 1998), but is distinct from the CnWB phytoplasma (Fig. 1). It has been reported that different phytoplasmas may cause 
similar symptoms in the same host plant. Examples include grapevine infected by flavescence dorée or bois noir phytoplasmas (Daire et al., 1993) and Spanish broom (Spartium junceum) infected by apple proliferation or elm yellows phytoplasmas (Marcone et al., 1996). Thus, it is possible that the CLL and CnWB diseases, which sometimes show similar symptoms, are caused by distinct phytoplasma species, the CLL and CnWB phytoplasmas. Nucleotide sequence analyses of PCR-amplified 16S rDNA and phylogenetic analyses of $16 \mathrm{~S}$ rDNA sequences revealed that the CnWB phytoplasma is not related to AY, unlike CLL, but is more closely related to isolates of coconut phytoplasmas. These data suggest strongly that the CnWB phytoplasma is a novel phytoplasma that infects chestnut trees.

\section{LY and related strains}

The grouping of the coconut phytoplasmas is controversial. For instance, Liefting et al. (1996) included isolates LY, LDY, LD and PPWB in a phylogenetic analysis and recognized that these strains formed a cluster. They proposed naming this group as a seventh 'strain cluster', after the classification system of Seemüller et al. (1994) and Schneider et al. (1995). However, Tymon et al. (1998) showed that PPWB and coconut phytoplasmas should be separated into different clusters in a phylogenetic analysis and recognized that the coconut phytoplasma cluster formed three distinct 'subclades': (i) LY and LDY, (ii) LDT and (iii) LDG and LDN. According to the classification system of Gundersen et al. (1994a), these were respectively named subclades vii, xii and xiv. Conversely, Lee et al. (1998) determined that these strains formed two subclades, VI (PPWB) and VII (LY, LDY and LD), using a phylogenetic analysis of nearly fulllength 16S rDNA sequences from 42 diverse phytoplasmas. Thus, the coconut phytoplasma group is now considered to represent a unique and distinct primary group. In our study, we found that PPWB should be separated from five coconut phytoplasmas plus CnWB phytoplasma and, thus, it forms a different cluster in a phylogenetic analysis, in agreement with previous work (Tymon et al., 1998; Lee et al., 1998).

\section{PCR specific for CnWB phytoplasma}

A primer set was designed using the CnWB phytoplasma $16 \mathrm{~S}$ rDNA sequence. The primers were forward primer CnWBF1 (5'-CTAGTTTAAAAACAATGCTC-3', corresponding to nucleotides 587-606 in the CnWB 16S rDNA sequence) and reverse primer CnWBR1 (5'-CTCATCTTCCTCCAATTC-3', complementary to nucleotides 1145-1162). In PCR samples containing CnWBF1 and CnWBR1, a 575-bp DNA fragment was amplified when the template DNA was derived from plants naturally affected by CnWB disease. No amplifications were observed when the template was derived from healthy plants (data not shown). In the future, this primer pair will facilitate the screening of putative insect vectors for the diseases found in Korea, although transmission of the phytoplasma has not yet been identified in the field.

\section{Phytoplasma signature sequences and unique $16 \mathrm{~S}$ rDNA sequences}

The 16S rDNA sequence of the CnWB phytoplasma was compared with sequences from 110 other phytoplasmas. Of three sequences reported previously to be unique to phytoplasmas (Gundersen et al., 1994b; Namba et al., 1993b), TTTTAAAAG (at positions 187-195) and GCTT (224-227) were found in the 16S rDNA sequence of the CnWB phytoplasma. However, the sequence ACTGGA (155-160) has a G at position 155 in the 16S rDNA sequence of CnWB and coconut phytoplasmas (LDG, LDN, LDT, LDY and LY). Additionally, in the CnWB sequence, the nucleotide at position 156 is T. Furthermore, GTGT (276-279) and CCC (487-489) sequences unique to phytoplasmas have a $\mathrm{T}$ at positions 278 and 487 in the $16 \mathrm{~S}$ rDNA of the CnWB phytoplasma.

In addition to the above unique sequences, the $16 \mathrm{~S}$ rDNA of the CnWB phytoplasma contains other unique sequences compared with all other phytoplasmas studied. For example, single bases of the CnWB phytoplasma 16S rDNA differed from the corresponding sequences in coconut phytoplasmas as well as all other phytoplasmas at positions $128(\mathrm{G}$ to A), 232 (C to A), 262 (A to C), 463 (C/G/T to A), 597 (C/G/T to A), 650 (A to $\mathrm{G}$ ), 884 ( $\mathrm{G}$ to $\mathrm{A}$ ), 909 (C to T), 990 (A/G/T to C), 999 (T/C to G), 1124 ( $\mathrm{T}$ to $\mathrm{C}$ ), 1145 (A to $\mathrm{G}$ ) and 1158 ( $\mathrm{G}$ to $\mathrm{A}$ ).

In comparisons of the CnWB phytoplasma with the coconut phytoplasmas, there are base differences between CnWB and LY, LDT and LDG/LDN at 44, 37 and 44 positions, respectively. Single bases at positions 248 ( $\mathrm{T}$ to $\mathrm{A}$ ), 497 (C to $\mathrm{T}$ ), 526 ( $\mathrm{G}$ to $\mathrm{A}$ ), 598 ( $\mathrm{T}$ to $\mathrm{A}$ ), 602 (C to T), 606 ( $\mathrm{T}$ to $\mathrm{C}$ ), 638 (A to $\mathrm{T}$ ), 657 (C to T), 684 ( $\mathrm{T}$ to $\mathrm{C}$ ), 709 (G to A), 822 (G to T), 1120 ( $\mathrm{G}$ to $\mathrm{C}$ ), 1127 ( $\mathrm{G}$ to $\mathrm{A}$ ), 1166 ( $\mathrm{T}$ to $\mathrm{C}$ ), 1221 (A to $\mathrm{G}$ ), 1223 ( $\mathrm{T}$ to $\mathrm{G}$ ), 1268 (A to $\mathrm{G}$ ), 1269 ( $\mathrm{T}$ to $\mathrm{C}$ ) and 1331 (C to $\mathrm{T}$ ) differ between the CnWB phytoplasma and the coconut phytoplasmas. The presence of CnWBspecific signature sequences and sequences unique to the CnWB phytoplasma in the $16 \mathrm{~S}$ rDNA also supported this proposition and provided evidence for the genetic divergence of this pathogen from other phytoplasmas. Therefore, we conclude that $\mathrm{CnWB}$ is a phylogenetically distinct taxon.

\section{Phytoplasma phylogenetic classification}

In this study, by including almost all available phytoplasma $16 \mathrm{~S}$ rDNA sequences (110 sequences) in a single phylogenetic tree, the relationships among reported strains were made clearer (Fig. 1). Evidently, the phylogenetic tree we generated can be divided into several major clusters, which are supported by high bootstrap values. Thus, a total of eight distinct phytoplasma monophyletic groups based on $16 \mathrm{~S}$ rDNA sequences can now be recognized. These groups 
are as follows: 16S-group I, AY and related strains; $16 \mathrm{~S}$-group II, apple proliferation (AP) and related strains; 16S-group III, peanut witches' broom (PnWB) and related strains; 16 S-group IV, Canadian peach Xdisease $(\mathrm{CX})$ and related strains; $16 \mathrm{~S}$-group $\mathrm{V}$, pigeon pea witches' broom (PPWB) and related strains; 16Sgroup VI, LY and related strains; 16S-group VII, rice yellow dwarf (RYD) and related strains; and 16Sgroup VIII, EY and related strains. Our classification of phytoplasmas into ' $16 \mathrm{~S}$-groups' is generally in good accord with previously reported classifications into 'groups' or 'subclades' (Seemüller et al., 1998). However, the '16S-groups' have two notable features: (i) they use almost all reported sequences (110 sequences) as opposed to 'groups' or 'subclades' that used limited numbers of sequences and (ii) the numbering of the $16 \mathrm{~S}$-groups concurs with the branching order in the whole tree.

Any pair of phytoplasmas belonging to different $16 \mathrm{~S}$ groups is so phylogenetically different that the similarity of $16 \mathrm{~S}$ rDNA sequences between the two is always lower than $96 \%$. If $97 \%$ similarity is regarded as the threshold for defining species, as discussed above (Stackebrandt \& Goebel, 1994), this indicates that each 16S-group contains multiple taxa comparable to 'species'. Therefore, in an attempt to clarify relationships between phytoplasma isolates further within an individual 16S-group, we divided each 16Sgroup further into smaller taxa when the similarity of the 16S rDNA sequences of two isolates was less than $97 \%$ or when two isolates showed clear biological isolation, such as striking heterogeneity in host plants and insects. Since the phytoplasma is an endocellular microbe and is totally dependent on its hosts, the second criterion should be important for phytoplasma classification. Using such criteria, we identified 29 distinct smaller taxa or 'subgroups'. In the phytoplasma phylogeny, six Candidatus species have so far been registered (Fig. 1) and each Candidatus species corresponds well to a 'subgroup' proposed here. When one looks at Fig. 1, one may think that other $16 \mathrm{~S}$-groups are possible. For example, the largest 16Sgroup, 16S-group I, could be divided into two $16 \mathrm{~S}$-groups, 16S-groups $\mathrm{Ia}$ and $\mathrm{Ib}$, respectively containing the AY subgroup and the STRWB1/JHP/IBS/ AUSGY/STOL subgroups. However, the highest 16S rDNA sequence similarities between members of the AY subgroup and those of the STRWB1/JHP/ IBS/AUSGY/STOL subgroups were $96.5 \%$ (between $\mathrm{RaPh}$ and VK), 96.4\% (between $\mathrm{RaPh}$ and STOL) and $96.2 \%$ (between KV and STOL), which are higher than the allowed similarity between any of the proposed 16S-groups (always less than 96\%). Thus, we conclude that the eight $16 \mathrm{~S}$-groups proposed in this paper are appropriate at present.

\section{Conclusions}

We have identified the pathogen that causes CnWB disease in Japanese chestnut trees in Korea as a novel species of phytoplasma, CnWB phytoplasma. So far, the phylogenetic analysis of phytoplasmas found in chestnut trees from Korea and elsewhere has been limited. Phylogenetic analyses indicated that the CnWB phytoplasma constitutes a clearly defined subgroup and belongs to 16S-group VI, together with the LY, LDG and LDT subgroups. Furthermore, its 16S rDNA sequence dissimilarity, signature sequences and phylogenetic position distinguish it as a novel species. In addition, in a PCR approach using a primer pair specific to CnWB (CnWBF1/CnWBR1), specific amplifications provided evidence for a novel phytoplasma species.

We propose that the CnWB phytoplasma be designated as a novel, distinct Candidatus species, 'Candidatus Phytoplasma castaneae', with the following description: 'Candidatus Phytoplasma castaneae' [(Mollicutes): NC; NA; O; NAS (GenBank acc. no. AB054986), oligonucleotide sequences of unique regions of the 16S rDNA 5'-CTAGTTTAAAAACAATGCTC-3' (587-606) and 5'-CTCATCTTCCTCCAATTC-3' (1145-1162) (Castanea, phloem); $\mathrm{M}]$.

\section{ACKNOWLEDGEMENTS}

We thank Mr Shigeru Hatano for his excellent technical assistance. This work was supported partly by Grants-inAid of Scientific Research from the Japan Society for the Promotion of Science (JSPS) (nos 09460155 and 13306004) and by the Program for the Promotion of Basic Research Activities for Innovative Biosciences (PROBRAIN) of the Bio-oriented Technology Research Advancement Institution.

\section{REFERENCES}

Ahrens, U. \& Seemüller, E. (1992). Detection of DNA of plant pathogenic mycoplasma-like organisms by a polymerase chain reaction that amplifies a sequence of the $16 \mathrm{~S}$ rRNA gene. Phytopathology 82, 828-832.

Daire, X., Clair, D., Larrue, J. \& 11 other authors (1993). Occurrence of diverse MLOs in tissues of grapevine affected by grapevine yellows in different countries. Vitis 32, 247-248.

Davis, R. E., Dally, E. L., Gundersen, D. E., Lee, I.-M. \& Habili, N. (1997). "Candidatus Phytoplasma australiense," a new phytoplasma taxon associated with Australian grapevine yellows. Int J Syst Bacteriol 47, 262-269.

Deng, S. \& Hiruki, C. (1991). Genetic relatedness between two nonculturable mycoplasma-like organisms revealed by nucleic acid hybridization and polymerase chain reaction. Phytopathology 81, 1475-1479

Griffiths, H. M., Sinclair, W. A., Smart, C. D. \& Davis, R. E. (1999). The phytoplasma associated with ash yellows and lilac witches'-broom: 'Candidatus Phytoplasma fraxini'. Int J Syst Bacteriol 49, 1605-1614.

Gundersen, D. E. \& Lee, I.-M. (1996). Ultrasensitive detection of phytoplasmas by nested-PCR assays using two universal primer pairs. Phytopathol Mediterr 35, 144-151.

Gundersen, D. E., Lee, I.-M., Rehner, S. A., Davis, R. E. \& Kingsbury, D. T. (1994a). Phylogeny of mycoplasmalike organisms (phytoplasmas): a basis for their classification. J Bacteriol 176, 5244-5254

Gundersen, D. E., Lee, I.-M., Chang, C. J. \& Davis, R. E. (1994b). RFLP analyses of ribosomal protein genes reveal strain diversity in MLO 16S rRNA groups I and III. Phytopathology 84, 1128. 
Han, S. S., Kim, Y. H., So, I. Y. \& Chai, J. K. (1997). Association of phytoplasma with chestnut (Castanea crenata Sieb. et Zucc.) little leaf disease in Korea. J Mycoplasmol Kor 8, 48-54.

Hiruki, C., Wang, K., Ceranic-Zagorac, P., Han, S. S. \& Cousin, M. T. (1998). A comparative study of phylogenesis in phytoplasmas of different origins by restriction fragment length polymorphism analysis and heteroduplex mobility assay of phytoplasma genetic DNA. IOM Lett 5, 121.

Kimura, M. (1980). A simple method for estimating evolutionary rates of base substitutions through comparative studies of nucleotide sequences. J Mol Evol 16, 111-120.

Kirkpatrick, B. C. (1992). Mycoplasma-like organisms: plant and invertebrate pathogens. In The Prokaryotes, pp. 4050-4067. Edited by A. Balows, H. G. Trüper, M. Dworkin, W. Harder \& K. H. Schleifer. New York: Springer.

Kuske, C. R. \& Kirkpatrick, B. C. (1992). Phylogenetic relationships between the western aster yellows mycoplasmalike organism and other prokaryotes established by $16 \mathrm{~S}$ rRNA gene sequence. Int $J$ Syst Bacteriol 42, 226-233.

Lee, I. M., Hammond, R. W., Davis, R. E. \& Gundersen, D. E. (1993). Universal amplification and analysis of pathogen 16S rDNA for classification and identification of mycoplasma-like organisms. Phytopathology 83, 834-842.

Lee, I.-M., Gundersen-Rindal, D. E., Davis, R. E. \& Bartoszyk, I. M. (1998). Revised classification scheme of phytoplasmas based on RFLP analyses of $16 \mathrm{~S}$ rRNA and ribosomal protein gene sequences. Int $J$ Syst Bacteriol 48, 1153-1169.

Liefting, L. W., Andersen, M. T., Beever, R. E., Gardner, R. C. \& Forster, R. L. S. (1996). Sequence heterogeneity in the two 16S rRNA genes of Phormium yellow leaf phytoplasma. Appl Environ Microbiol 62, 3133-3139.

Marcone, C., Ragozzino, A., Schneider, B., Lauer, U., Smart, C. D. \& Seemuller, E. (1996). Genetic characterization and classification of two phytoplasmas associated with spartium witches' broom disease. Plant Dis 80, 365-371.

McCoy, R. E., Cauldwell, A., Chang, C. J. \& 16 other authors (1989). Plant diseases associated with mycoplasma-like organisms. In The Mycoplasmas, vol. 5, pp. 545-640. Edited by R. F. Whitcomb \& J. G. Tully. New York: Academic Press.

Mittempergher, L. \& Sfalanga, A. (1998). Chestnut yellows: a new disease for Europe. Phytopathol Mediterr 37, 143-145.

Montano, H. G., Davis, R. E., Dally, E. L., Pimentel, J. P. \& Brioso, P. S. T. (2000). Identification and phylogenetic analysis of a new phytoplasma from diseased chayote in Brazil. Plant Dis 84, 429-436.

Montano, H. G., Davis, R. E., Dally, E. L., Hogenhout, S., Pimentel, J. P. \& Brioso, P. S. T. (2001). ' Candidatus Phytoplasma brasiliense', a new phytoplasma taxon associated with hibiscus witches' broom disease. Int J Syst Evol Microbiol 51, 1109-1118.

Namba, S., Kato, S., Iwanami, S., Oyaizu, H., Shiozawa, H. \& Tsuchizaki, T. (1993a). Detection and differentiation of plant-pathogenic mycoplasmalike organisms using polymerase chain reaction. Phytopathology 83, 786-791.
Namba, S., Oyaizu, H., Kato, S., Iwanami, S. \& Tsuchizaki, T. (1993b). Phylogenetic diversity of phytopathogenic mycoplasmalike organisms. Int J Syst Bacteriol 43, 461-467.

Okuda, S., Doi, Y. \& Yora, K. (1974). Mycoplasmalike bodies associated with chestnut yellows. Ann Phytopathol Soc Jpn 40, 464-468.

Prince, J. P., Davis, R. E., Wolf, T. K., Lee, I.-M., Mogen, B. D., Dally, E. L., Bertaccini, A., Credi, R. C. \& Barba, M. (1993). Molecular detection of diverse mycoplasma-like organisms (MLOs) associated with grapevine yellows and their classification with aster yellows, Xdisease and elm yellows MLOs. Phytopathology 83, 1130-1137.

Saitou, N. \& Nei, M. (1987). The neighbor-joining method: a new method for reconstructing phylogenetic trees. Mol Biol Evol 4, 406-425.

Sawayanagi, T., Horikoshi, N., Kanehira, T., Shinohara, M., Bertaccini, A., Cousin, M.-T., Hiruki, C. \& Namba, S. (1999). 'Candidatus Phytoplasma japonicum', a new phytoplasma taxon associated with Japanese Hydrangea phyllody. Int J Syst Bacteriol 49, 1275-1285.

Schneider, B., Cousin, M. T., Klinkong, S. \& Seemüller, E. (1995). Taxonomic relatedness and phylogenetic positions of phytoplasmas associated with diseases of faba bean, sunhemp, sesame, soybean and eggplant. Z Pflanzenkr Pflanzenschutz 102, 225-232.

Seemüller, E., Schneider, B., Mäurer, R. \& 8 other authors (1994). Phylogenetic classification of phytopathogenic mollicutes by sequence analysis of 16S ribosomal DNA. Int J Syst Bacteriol 44, 440-446.

Seemüller, E., Marcone, C., Lauer, U., Ragozzino, A. \& Göschl, M. (1998). Current status of molecular classification of the phytoplasmas. J Plant Pathol 80, 3-26.

Shimada, C. \& Kouda, S. (1954). Yellowing disease of chestnut. Ann Phytopathol Soc Jpn 19, 95.

Stackebrandt, E. \& Goebel, B. M. (1994). Taxonomic note: a place for DNA-DNA reassociation and 16S rRNA sequence analysis in the present species definition in bacteriology. Int J Syst Bacteriol 44, 846-849.

Thompson, J. D., Higgins, D. G. \& Gibson, T. J. (1994). CLUSTAL W: improving the sensitivity of progressive multiple sequence alignment through sequence weighting, position-specific gap penalties and weight matrix choice. Nucleic Acids Res 22, 4673-4680.

Tymon, A. M., Jones, P. \& Harrison, N. A. (1997). Detection and differentiation of African coconut phytoplasmas: RFLP analysis of PCR-amplified 16S rDNA and DNA hybridization. Ann Appl Biol 131, 91-102.

Tymon, A. M., Jones, P. \& Harrison, N. A. (1998). Phylogenetic relationships of coconut phytoplasmas and the development of specific oligonucleotide PCR primers. Ann Appl Biol 132, 437-452.

White, D. T., Blackall, L. L., Scott, P. T. \& Walsh, K. B. (1998). Phylogenetic positions of phytoplasmas associated with dieback, yellow crinkle and mosaic diseases of papaya, and their proposed inclusion in 'Candidatus Phytoplasma australiense' and a new taxon, 'Candidatus Phytoplasma australasia'. Int J Syst Bacteriol 48, 941-951.

Zreik, L., Carle, P., Bové, J. M. \& Garnier, M. (1995). Characterization of the mycoplasmalike organism associated with witches'-broom disease of lime and proposition of a Candidatus taxon for the organism, "Candidatus Phytoplasma aurantifolia". Int J Syst Bacteriol 45, 449-453. 